第64巻第 3 号岩石鉱物鉱床学会誌 1970 年 9 月 5 日

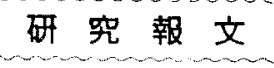

\title{
INTRUSIVE VOLCANIC BRECCIAS IN THE LATE MESOZOIC ZENJOJI-YAMA FORMATION IN WESTERN CHUGOKU AND THEIR POSSIBLE RELEVANCE TO THE FORMATION OF CAULDRON STRUCTURE
}

\author{
Nobuhide Murakami* and Hideo Matsusato** \\ * Geological Institute, Facully of Liberal Arts, Yamaguchi \\ University, Yamaguchi \\ ** Yamaguchi Chuo High School, Yamaguchi
}

\section{INTRODUGTION}

There are vastly distributed late Mesozoic acid volcanic rocks in Southwest Japan. They are composed largely of rhyolitic to dacitic pyroclastics, mainly welded, with subordinate amounts of andesitic rocks. Their entire thickness is estimated at 500 to $2000 \mathrm{~m}$ or even more, and the total volume is supposed to be of $10^{3}$ to $10^{4} \mathrm{~km}^{3}$ order in each eruption province. In recent years, many elaborate works have been done on these volcanics especially from the stratigraphical viewpoint, as summarized in 1967 (Research Group for LMIA, 1967) and 1968 (Ichikawa ct al., 1968). Through these works, the stratigraphy, component rock types and correlation of the volcanic formations became clear. As for the mode of emplacement of the volcanics and their tectonic relations, however, many problems remain unsolved. In this paper, some remarks are made on these problems on the basis of geological and petrographical data, especially on the volcanic breccias*** in the Zenjoji-yama formation of western Chugoku.

\section{GEOLOGY OF ZENJOJI-YAMA FORMATION}

In western Chugoku, the late Mesozoic acid volcanic formations are divided into two groups, Shunan and $\mathrm{Abu}$, each of which is somewhat different in

Manuscript received, May 15, 1970

*** This term is after the denomination by Wright and Bowes (1963) and Fisher (1960). 
component rock types and mode of emplacement of volcanics.

The Abu group overlying the Shunan group unconformably, consists essentially of rhyolitic to rhyodacitic welded tuff intercalated with thin tuffaceous sediments of lacustrine origin which are predominant in the lowermost horizon. Dacitic to andesitic tuff and tuff breccia are also interbedded in the lower and upper horizons. The total thickness is summed up to 2000 to $2500 \mathrm{~m}$ or more. Distribution of the Abu group is confined to the area extending from the Chugoku mountainland to the Sanin district. The mode of emplacement of these volcanics has not been ascertained, although there are some evidences possibly suggesting collapse of a large scale comparable to the volcano-tectonic depression proposed by Smith (1960), as deduced from the long continuous fault breccia zone in the contact area with basement rocks.

The Shunan group is distributed on the southern side of the Chugoku mountainland and in the Setouchi area with a roughly E-W trend. It is subdivided into two formations, Monomigatake formation in the northern part and Zenjoji-yama formation in the southern part. These two formations have a close resemblance in the component rocks, stratigraphy and geologic structure. The Monomigatake formation was investigated in detail by Nishino and Murakami (1965) mainly from a geological and stratigraphical standpoint, although any satisfactory results on the emplacement of the volcanic rocks have not been obtained.

The Zenjoji-yama formation is made up of four separate masses, each trending E-W. They are named Kibe, Zenjoji-yama, Hirano and Taika-zan masses from west to east (Fig. 1). As will be clarified later, each mass is supposed to have been the site of volcanic activity independent from the others. The following four stages are discernible in the formation of these masses.

Stage I: Andesitic lava, tuff and lapilli tuff.

Stage II: It is divisible into three substages in the order of deposition.

IIa: Dacitic to rhyodacitic tuff, lapilli tuff and welded tuff.

IIb: Dacitic to rhyodacitic tuffaceous sediments of lacustrine origin, often with intercalation of thin black shale.

IIc: Rhyolitic tuff and lapilli tuff.

Stage IIr: Dacitic to rhyodacitic volcanic breccias, with small amounts of welded tuff, tuff and tuff breccia.

Stage VI: Plutonic intrusives consisting of gabbro, quartz diorite and granodiorite, intruded by aplitic veins.

Kibe mass (Fig. 2)

This mass comprises all four stages of igneous activity. It is about 14 $\mathrm{km}$ in $\mathrm{E}-\mathrm{W}$ extension and about $5 \mathrm{~km}$ in width. The andesitic rocks of stage $\mathrm{I}$, mainly tuffaceous and over $100 \mathrm{~m}$ in thickness, are exposed in the northern 


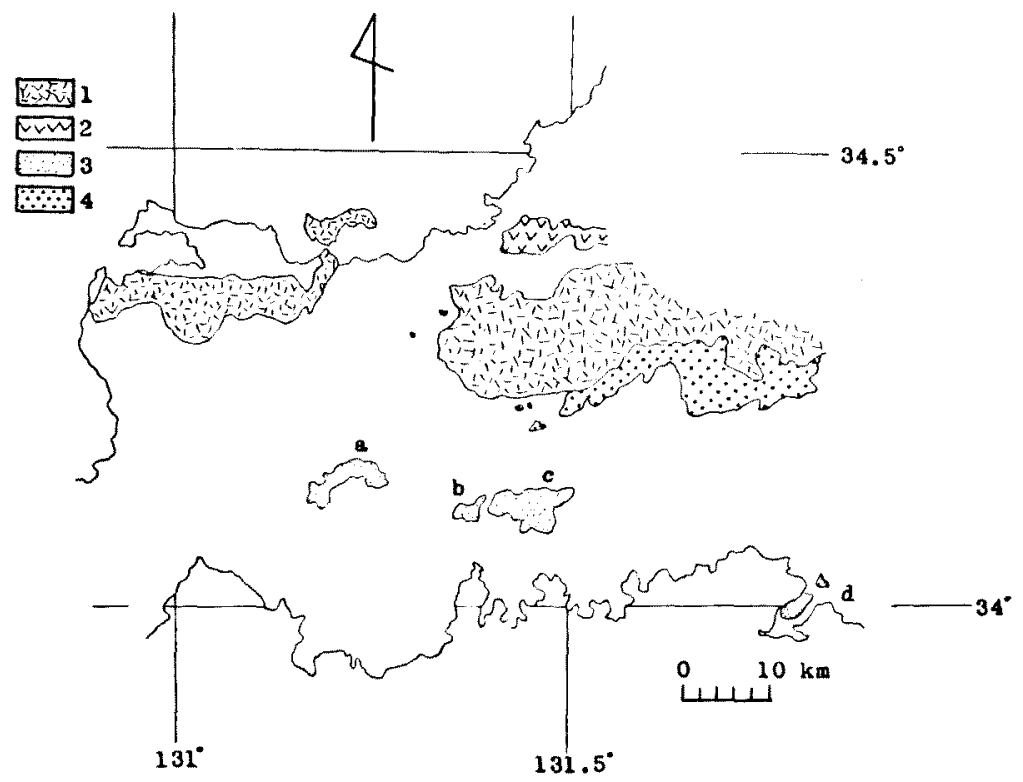

Fig. 1. Distribution of late Mesozoic volcanic formations in West Chugoku.

1: Abu group. 2: Tadokoyama volcanic formation (Probably corresponding to the Shunan group). 3: Zenjoji-yama formation. 4: Monomigatake formation. $\mathrm{a}, \mathrm{b}, \mathrm{c}$ and $\mathrm{d}$ represent Kibe, Zenjoji-yama, Hirano and Taika-zan masses, respectively.

margin, divided from the upper Paleozoic formations by arcuate fault. They occur also as abundant fragments of valiable size in volcanic breccias. Weak bedding is common (Fig. 11a), and feeble welding is frequently observed. The volcanics of stage II, about $200 \mathrm{~m}$ thick, have a limited distribution in the northern part, although they also occur as large blocks in the volcanic breccias. They overlie the andesitic rocks conformably and are composed of rhyolitic tuffs intercalated with dacitic to rhyolitic tuffaceous sediments of about $20 \mathrm{~m}$ thickness in the lowermost horizon. The component rocks of the sediments are tuffaceous sandstone and conglomerate without shale. Grading is often distinct, faint false bedding being visible uncommonly (Fig. 11b). The rhyolitic tuffs are homolithologic presenting a massive appearance, and lacking bedding, grading and other features characteristics to the ordinary sediments. Welding is obscured too, possibly due to the presence of abundant phenocrystic minerals such as quartz, plagioclase and potash feldspar, whereas lithic fragments are usually of small amounts. 


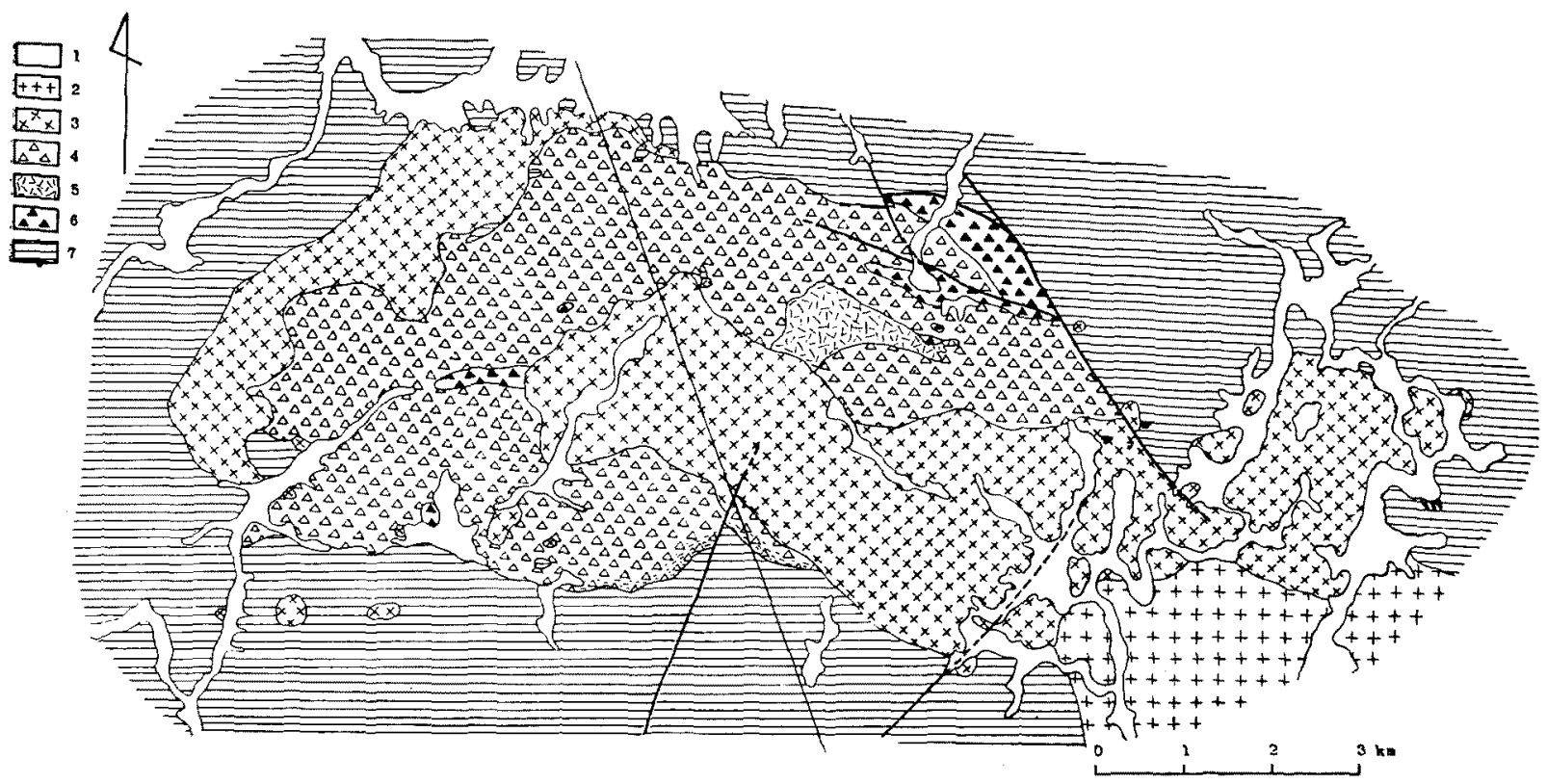

Fig. 2, Geological map of the Kibe area, Yamaguchi Prefecture.

1: Quaternary. 2: Late Mesozoic granites. 3: Basic to intermediate plutonic complex of stage IV. 4: Volcanic breccias of stage III. Hatched area corresponds to the portion poured out on the surface. 5: Volcanic formation of stage II. 6: Volcanic formation of stage I. 7: Basement rocks (Kwanmon group, upper Palaeozoic formation and Sangun metamorphic rocks). 
Intrusive volcanic breccias in the late Mesozoic Zenjoji-yama formation 77

Volcanic breccias of stage III have the widest distribution of all volcanics. A large part of them intrudes older volcanics and basement rocks with an almost vertical inclination (Fig. 11c), while in the southern margin they overlie the late Cretaceous Kwanmon group with a parallel unconformable relation. Besides the main mass, some breccia dikes with a width of 1 to $5 \mathrm{~m}$ are found in the basement rocks. To the naked eye, these breccias have a conspicuously heterogeneous appearance owing to the presence of abundant lithic fragments (Fig. 11d) which are somewhat in lesser amounts in the southern part.

The fragments are set in the matrix consisting of fine clasts of minerals, lithic fragments and pumiceous materials. They are variable in size, ranging from several millimeters to several meters in diameter (Fig. 11e). The largest one attains to 5 meters or more. They are angular to subangular, occasionally rounded. Some andesitic and sedimentary rock fragments, having an elongated rugged outline, are arranged roghly along the flow plane shown by the alignment of the pumiceous materials (Fig. 11 i. j.). The larger part of these fragments* is composed of basement rocks (Palaeozoic and Kwanmon group) and volcanics belonging to stages I and II. Rarely fine schistose rocks are included, whose source has not been identified. Some basement rock fragments are slightly vitrified along periphery. They tend to be rounded in outline. On the other hand, the fragments belonging to stages I and II are generally angular to subangular (Fig. 3), rounded ones being scarce. Some aggregates of fragments

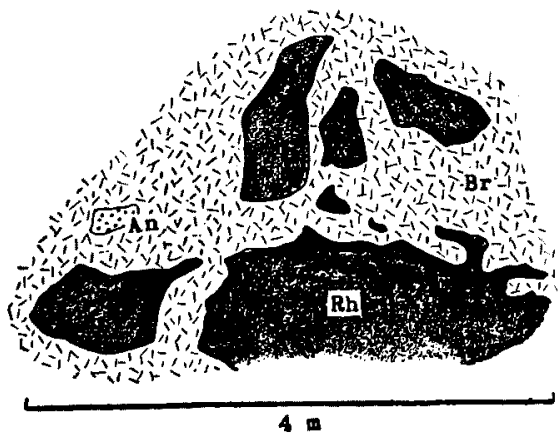

Fig. 3. Sketch showing the occurrence of volcanic rock fragments in volcanic breccia.

An: Andesitic, rock. Rh: Rhyolitic pyroclastic rock.

Br: Volcanic breccia.

* In the southern part, occasionally occur granodioritic fragments which are considered to have been emplaced just after the Kwanmon volcanism (Research Group for LMIA, 1967). 
in which the fractures are filled with fine clastic minerals, apparently exhibit the fragmentation in situ or near the present location. From the above description, it can be presumed that the rounded and vitrified basement rock fragments have been derived from a source deeper than that of the angular volcanic ones. A somewhat regular rclation is found between the level of distributio: of the volcanic fragments and their rock types.

1) Tive fragments of stage II are plentiful at the level higher than those of stage $I$. The former are more angular and larger in size than the latter. Their distribution is confined to the central part of the volcanic mass and conformable to the formation of stage II.

2) The fragments of stage I are widely scattered within the breccias. There is a tendency that the fragments are smaller in amount and more rounded at the higher level. It is noticed that the fragments of stage $I$ are abundant even at the contact horizon with the basement rocks. These results appear to indicate that the fragmentation of the volcanics of stage II took place at the present level or adjacent to it, whereas the volcanics of stage I suffered fragmentation in the lower level, some of them in the deeper part.

The pumiccous matcrials of 1 to 15 millimeters in width have lenticular or elongated irregular shapes and appear to be arranged parallel to the wall around blocks (Fig. 11 h.i.j.). Within the breccia mass they extend roughly in the vertical direction, giving a finely undulating appearance. Distribution of the phenocrysts in them is characteristic. As shown in Fig. 4, fine lenticular aphyric part is often surrounded by porphyritic part, and is also intermixed with the latter with comparatively sharp boundaries. This leads to the assumption that these materials were seoarated under a fairly high explosive condition before consolidation.

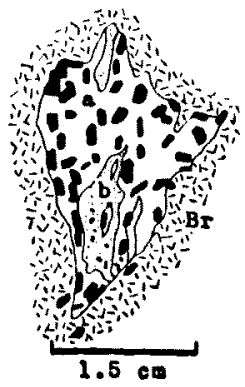

Fig. 4. Sketch showing the occurrence of pumiceous material in volcanic breccia.

a: Porphyritic part. b: Aphyric part. Br: Volcanic breccia. Black solid portion: Plagioclase crystal. 
Intrusive volcanic breccias in the late Mesozoic Zenjoji-yama formation 79

The volcanic rocks of stage I to III are penetrated by the elongated ringshaped plutonic complex of stage IV. The complex has an extension of about $14 \mathrm{~km}$ and a width of 4 to $5 \mathrm{~km}$. The larger part of the component rocks is quartz diorite which is accompanied by granodiorite, xenolithic quartz gabbro and aplite vein. As a whole, they are characterized by the semi-porphyritic texture and micrographic intergrowth of quartz and alkali feldspar in the groundmass of gabbro to granodiorite. The dominant mafic mincrals are augite, hypersthene, hornblende and biotite, although the first two minerals are confined to quartz gabbro and quartz diorite. The petrography of these plutonics was formerly investigated by Murakami (1960).

Zenjoji-yana mass (Fig. 5)

The geological relations of this mass to the basement rocks are divided into the following three cases.

1) Intrusion of the volcanic breccias of stage III into the Kwanmon group and Izuruha acid rocks composed of granodiorite and plagiophyre (Murakami, 1960).

2) Unconformable relation of the tuff and welded tuff of stage III to the basement Kwanmon group. The latter is usually affected by severe brecciation and permeation of pumiceous materials probably derived during the volcanism in stage III.

3) Fault relation between this mass and the basement rocks (Kwanmon group, Sangun metamorphic rocks and Izuruha acid rocks). Part of this fault is supposed to have been formed in connection with the eruption of the volcanic rocks of stages I and II, as will be described later.

The rocks constituting this mass are various types of volcanic rocks of stage I to III, of which the volcanic breccias of stage III occupy the largest area. The plutonic rocks associated with these volcanics are absent.

Stage I: The andesitic rocks of stage I, about $600 \mathrm{~m}$ in thickness, are distributed in the limited area except for the blocks in volcanic breccias as shown in Fig. 5. They are composed of lava flow of uniform porphyritic texture in the eastern part, and tuff and tuff breccia in the northern and southern parts.

Stage II: Distribution of the rocks of stage II is more limited, although blocks of various sizes are abundant in the volcanic breccias of stage III. Most of them are tuffaceous sediments such as dacitic to rhyolitic tuffaceous sandstone and shale with interlayered thin black shale, of which the dacitic sediments occupy the lower horizon. The whole thickness is estimated at $50 \mathrm{~m}$ or more. Intense disturbance of these sediments is a noticeable fact. In many districts the sediments are variable in both strike and dip; e.g., they strike $N$ $50^{\circ} \mathrm{E}$ and $\operatorname{dip} 50^{\circ} \mathrm{NW}$ in the northeastern mass, $\mathrm{N} 80^{\circ} \mathrm{E}$ and $70^{\circ} \mathrm{N}$ in the eastern small mass. From detailed field observation, the disturbance is assumed to 


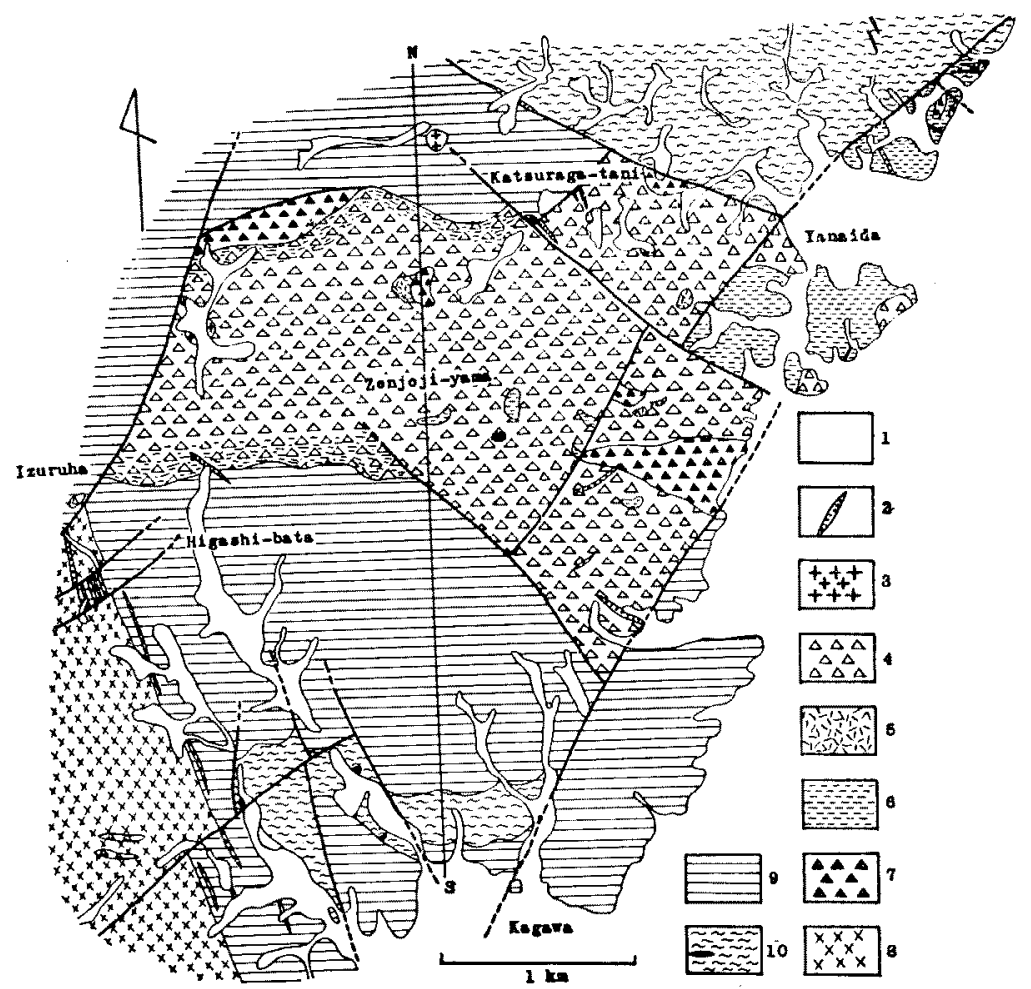

Fig. 5. Geological map of the Zenjoji-yama area, Yamaguchi Prefecture. 1: Quaternary. 2: Acidic dike (Quartz porphyry, granophyre and felsite). 4: Volcanic breccias. Hatched area corresponds to the portion poured out on the surface. 5: Rhyolitic pyroclastic rock. 6: Lacustrine sediments. 7: Volcanic formation of stage $\mathrm{I}$. 8: Izuruha acid rocks (Granodiorite, plagiophyre and aplite). 9: Kwanmon group. 10: Sangun metamorphic rocks and serpentinite.

be attributed to the collapse of this area and the upward shift of volcanic breccias associated with the underground brecciation at deeper level. Rhyolitic tuff and tuff breccia occur only as blocks in volcanic breccias, although they might have been distributed more broadly before the injection of the breccias.

Stage III: As described before, the volcanic breccias crop out most broadly of all volcanics. Most of the breccias intrude the older volcanic formations and basement rocks, whereas in some parts they cover the basement rocks unconformably. Where the latter relation is observed, the breccias become finegrained in both fragments and matrix, and are frequently welded. At 
Katsuragatani in the northern part of this mass, the breccias appear as alternating beds of fine tuff and tuff breccia covering the Kwanmon group which is highly brecciated and permeated by the pumiceous materials similar to those in the adjacent tuff. This may mean that the tuff and tuff breccia were poured out on the surface during a fairly violent explosion, accompanied by the brecciation of the basement Kwanmon group. Excluding these tuff and tuff breccia, two contrastive types are distinguished in the breccias. One is an ordinary type containing numerous clastic fragments and blocks set in the uniform massive matrix; the other type is poor in fragments and rich in short lenticular or vermicular, often streaky, pumiceous materials which seem to be arranged almost vertically, often in random directions. The latter type bears resemblance to flat-lying welded tuff, but it is devoid of eutaxitic texture. Usually the two types are gradational, although the latter tends to be common in the inner part of the mass. The rock type of the fragments is not seriously different from that in the Kibe mass, excepting the plentrifulness of the lacustrine sediments. The shape of these fragments is characteristic. As illustrated in Fig. 6, they mainly take an elongated form with irregular outline in shaly rocks, while they occur as somewhat rounded blocks in sandy rocks (Fig. $11 \mathrm{f} . \mathrm{g}$ ). Probably they might have been brecciated under an unconsolidated condition after the deposition. Their size is occasionally enormous, attaining to sevcral tens of meters.
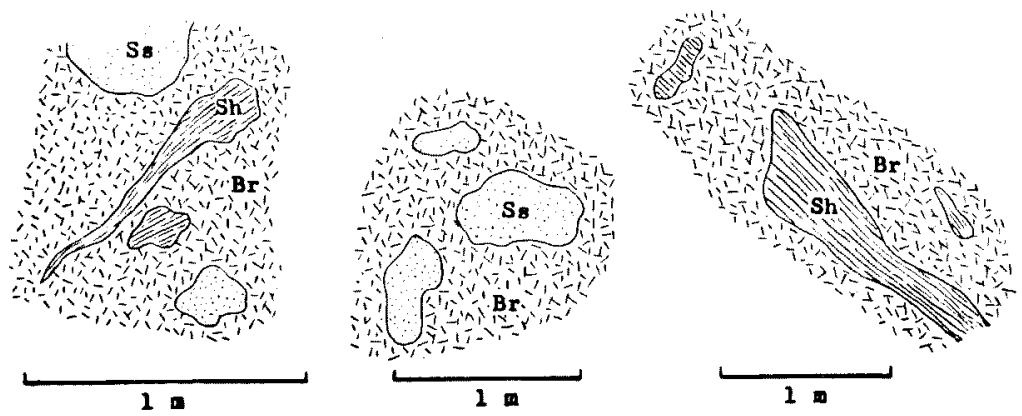

Fig. 6. Sketch showing the occurrence of lacustrine sediments in volcanic breccia.

Ss: Sandstone. Sh: Shale. Br: Volcanic breccia.

\section{Hirano mass (Fig. 7)}

This mass extends $E-W$ and consists of the volcanics ranging from stage $I$ to III. Associated with these volcanics, small stock-like masses of quartz diorite are found in some parts. The volcanics of stages I and II have the largest distribution of four masses, exceeding the Kibe mass. Andesitic rocks of 


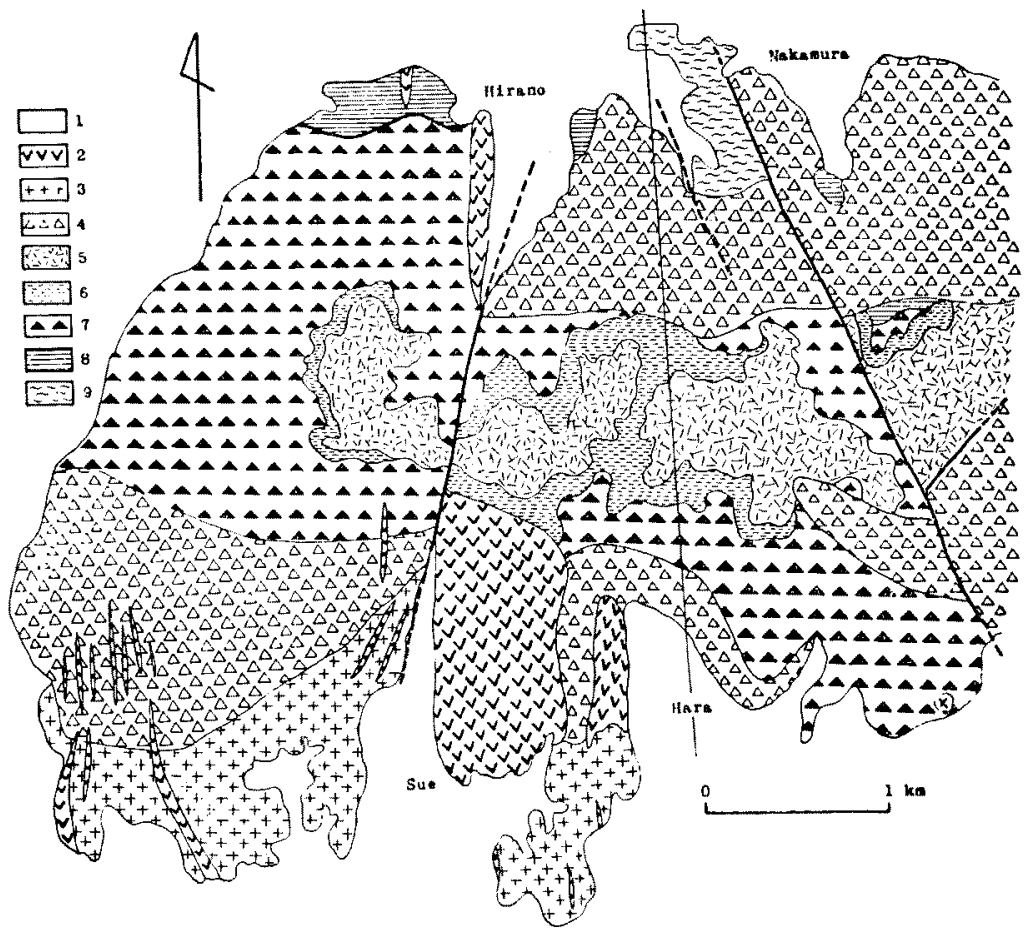

Fig. 7. Geological map of the Hirano area, Yamaguchi Prefecture.

1: Quaternary. 2: Acidic dike (Quartz porphyry, granophyre and felsite). 3: Late Mesozoic granites. 4: Volcanic breccias. 5: Rhyolitic pyroclastic rocks. 6 : Dacitic to rhyodacitic pyroclastic rocks intercalated with lacustrine sediments. 7: Volcanic formation of stage I, 8: Kwanmon group. 9: Sangun metamorphic rocks.

stage I over $450 \mathrm{~m}$ in thickness consist of the alternation of lava flow, tuff and tuff breccia, while the volcanics belonging to stage II with about $150 \mathrm{~m}$ thickness are composed essentially of dacitic to rhyolitic tuffaceous rocks. The latter begins with dacitic to rhyodacitic welded tuff gently dipping to the north at the lower horizon. It grades into rhyolitic fine tuff and phenocrystic crystalrich tuff of the upper horizon, through rhyodacitic to rhyolitic tuffaceous lacustrine sediments. These volcanics are surrounded by the volcanic breccias of stage III, along the contact with basement rocks (Sangun metamorphic rocks and IKwanmon group). The breccias are almost vertical-dipping intrusives abounding in lithic fragments in the northern part, while somewhat poor in the 
Intrusive volcanic breccias in the late Mesozoic Zenjoji-yama formation 83

southern part. Fine vermicular or streaky pumiceous materials similar to those at Katsuragatani are contained uncommonly.

The above-cited volcanics are intruded by the late Mesozoic granitic rocks.

Taika-zan mass

This mass is the smallest of four masses. It is composed of lower andesitic formation (about $200 \mathrm{~m}$ in thickness) and upper rhyolitic formation (about $200 \mathrm{~m}$ ). The latter has thin intercalation of lacustrine sediments. They overlie the Sangun metamorphic rocks and are intruded by the late Mesozoic granitic rocks. Any types of volcanic breccia have not yet been found.

\section{PETROGRAPHY AND PETROCHEMISTRY OF THE VOLGANIC ROCKS}

Volcanic rocks of stage $I$

As described before, two rock types are discerned in this stage, lava flow and tuffaceous rocks. The former is uniform in appearance with hyaloophitic to intersertal texture, while the latter is heterogeneous, especially varying in size and amount of fragments, a large part of which consists of various types of andesitic rocks. Exogenetic fragments are scarce. The matrix is usually massive, often welded. Main constitutents are plaigoclase (An 35-80), augite $\left(\beta=1.690-1.702,2 \mathrm{~V} z=49^{\circ}-51^{\circ}\right)$ and green hornblende $(\beta=1.660-1.665$, $\left.2 \mathrm{Vx}=70^{\circ}-75^{\circ}\right)$, orthopyroxene being rare. Alteration, such as uralitization, chloritization and albitization, is common. There is no great difference in chemical composition between the lava flow and the tuffaccous rocks.

\section{Volcanic rocks of stage II}

The volcanic rocks of this stage change their composition upward from dacitic to rhyolitic, with intercalation of tuffaceous sediments at the middle horizon. Welded texture is frequent, especially prominent at the lower horizon. The amount of fragments, largely endogeneous, is commonly limited to several per cent. When the fragments exceed this proportion, they are almost monolithic and devoid of both basement rock and andesite. The phenocrystic minerals are plagioclase (An 15-45), alkali feldspar $\left(2 \mathrm{Vx}=35^{\circ}-65^{\circ}\right)$, quartz and chloritized biotite. Hornblende is contained in dacitic tuff though in subordinate amount.

\section{Volcanic rocks of stage III}

The volcanic rocks of this stage occupy the largest proportion of all volcanics. They are dacitic to rhyodacitic in chemical composition as represented in Table 1. Thus a less acidified tendency which is opposite to that from stage I to II, must be noticed in the evolution of chemistry in the volcanic rocks. A large amount of clastic fragments is another feature of the volcanics of this stage, as the fragments amount usually to $30-50$ per cent, often attaining to 70 
Table 1. Chemical compositions of the volcanic

\begin{tabular}{|c|c|c|c|c|c|c|c|}
\hline No. & 1 & 2 & 3 & 4 & 5 & 6 & 7 \\
\hline Stage & I & I & I & I & I & I & II \\
\hline Mass & Kibe & Kibe & $\begin{array}{c}\text { Zenjoji- } \\
\text { yama }\end{array}$ & Hirano & Hirano & Hirano & Kibe \\
\hline $\mathrm{SiO}_{2}$ & 58.63 & 58.75 & 63.73 & 61.02 & 61,84 & 64.57 & 72.54 \\
\hline $\mathrm{TiO}_{2}$ & 0.87 & 0.69 & 0.54 & 0.40 & 0.65 & 0.60 & 0.02 \\
\hline $\mathrm{Al}_{2} \mathrm{O}_{3}$ & 17.58 & 16.98 & 15.81 & 16.72 & 15.88 & 15.63 & 14.74 \\
\hline $\mathrm{Fe}_{2} \mathrm{O}_{3}$ & 1.28 & 2.27 & 2. 42 & 1.60 & 1. 41 & 0.35 & 0.67 \\
\hline $\mathrm{FeO}$ & 5.09 & 4.89 & 2. 34 & 4. 55 & 3.85 & 4. 81 & 1. 18 \\
\hline $\mathrm{MnO}$ & 0.10 & 0.14 & 0.10 & 0.14 & 0.20 & 0.11 & 0.02 \\
\hline $\mathrm{MgO}$ & 2. 03 & 2.72 & 2.00 & 0.86 & 1.88 & 1. 60 & 0.32 \\
\hline $\mathrm{CaO}$ & 6.23 & 6.08 & 4.50 & 6.33 & 6.54 & 4. 68 & 2. 03 \\
\hline $\mathrm{Na}_{2} \mathrm{O}$ & 3.58 & 3.23 & 2.63 & 4. 66 & 3.60 & 3. 03 & 3. 44 \\
\hline $\mathrm{K}_{2} \mathrm{O}$ & 2. 19 & 2.17 & 3.13 & 2.75 & 1.75 & 2.77 & 5.36 \\
\hline $\mathrm{P}_{2} \mathrm{O}_{5}$ & 0.12 & n. d. & 0.09 & 0.21 & 0.24 & 0.18 & 0.06 \\
\hline $\mathrm{H}_{2} \mathrm{O}(+)$ & 1. 70 & 1.43 & 2.66 & 1.17 & 1.02 & 1.25 & 0.28 \\
\hline $\mathrm{H}_{2} \mathrm{O}(-)$ & 0.17 & 0.04 & 0.05 & 0.43 & 0.93 & 0.75 & 0.00 \\
\hline Total & 99.57 & 99.39 & 100.00 & 100.84 & 99.79 & 100.33 & 100.66 \\
\hline
\end{tabular}

Analyst: H. Matsusato $(1,2,7)$ and N. Murakami $(3-6,8-15)$

per cent or more, although welded parts poor in fragments are also found in less amount. The fragments comprise various types of rocks such as basement rocks, andesites, dacitic to rhyolitic tuffs and tuffaceous sediments. Pumiceous materials are rather poor, occasionally almost absent. As described before, the matrix of these volcanics is made up of fine clasts of lithic and pumiceous materials, and crystals. Plagioclase (An 20-50), quartz, green to brownish green hornblende $\left(\beta=1.666-1.680,2 \mathrm{Vx}=62^{\circ}-76^{\circ}\right)$ and chloritized biotite are dominant constituents. Alkali feldspar is usually absent except for the case derived from the rhyolitic tuffs and tuffaceous sediments. Pumiceous materials are usually altered to unidentified clay minerals and qaurtz, often to albite and carbonate, and more frequently to spherulitic aggregate of feldspar and quartz with chlorite and epidote. The last two minerals and carbonate occur also as fine veinlets and small aggregates and are dispersed in the matrix as irregularshaped crystals.

\section{MECHANISM OF EMPLAGEMENT OF VOLCANIG BRECCIAS AND THEIR RELATION TO TECTONIG MOVEMENT}

From the above data on each of the masses, the volcanism in the Zenjojiyama formation can be described as follows: 
Intrusive volcanic breccias in the late Mesozoic Zenjoji-yama formation 85 rocks in the Zenjoji-yama formation

\begin{tabular}{|c|c|c|c|c|c|c|c|}
\hline 8 & 9 & 10 & 11 & 12 & 13 & 14 & 15 \\
\hline II & II & II & III & III & III & III & III \\
\hline $\begin{array}{l}\text { Zenjoji- } \\
\text { yama }\end{array}$ & Hirano & Hirano & Kibe & $\begin{array}{c}\text { Zenjoji- } \\
\text { yama }\end{array}$ & $\begin{array}{c}\text { Zenjoji- } \\
\text { yama }\end{array}$ & $\begin{array}{c}\text { Zenjoji- } \\
\text { yama }\end{array}$ & Hirano \\
\hline 75. 16 & 69.15 & 76.03 & 61.15 & 66.00 & 68.71 & 69.91 & 65.39 \\
\hline 0. 10 & 0.37 & 0.07 & 0.71 & 0.48 & 0.33 & 0.30 & 0.50 \\
\hline 12.46 & 14.53 & 12.93 & 16.75 & 15.57 & 14. 39 & 14,69 & 14.52 \\
\hline 0.77 & 0.98 & 0.55 & 2.52 & 1.61 & 0.55 & 1.00 & 1.76 \\
\hline 0.20 & 3.03 & 0.58 & 3.50 & 2.95 & 2.40 & 1.62 & 3.03 \\
\hline 0.02 & 0.06 & 0.02 & 0.07 & 0.03 & 0.12 & 0.06 & 0.18 \\
\hline 0.31 & 1.53 & 0.20 & 1.84 & 0.49 & 0.48 & 0.58 & 1.10 \\
\hline 1.31 & 1.56 & 0.39 & 4.98 & 2.89 & 2. 94 & 2.18 & 3.42 \\
\hline 2.95 & 3.22 & 2.62 & 3.90 & 3. 37 & 3. 64 & 3.24 & 4.55 \\
\hline 5.35 & 4.31 & 4.60 & 2.77 & 2.71 & 4.16 & 4. 30 & 2.41 \\
\hline 0.01 & 0.10 & 0.02 & 0.10 & 0.03 & 0.11 & 0.03 & 0.16 \\
\hline 1.01 & 0.92 & 1.74 & 1.32 & 4.00 & 2.21 & 2.38 & 1. 72 \\
\hline 0.14 & 0.35 & 0.27 & 0.31 & 0.06 & 0.13 & 0.10 & 0.93 \\
\hline 99.79 & 100.11 & 100.02 & 99.92 & 100.19 & 100.17 & 100.39 & 99.67 \\
\hline
\end{tabular}

The volcanic activity began with eruption of andesitic rocks consisting of lava flow and pyroclastics. They might have been deposited on land as deduced from the presence of welded structure in the tuffaceous rocks and the absence of lacustrine sediments. Judging from the distribution of volcanic rocks, the eruption might have been connected with the fissures of $E-W$ trend in the basement rocks.

The subsequent volcanic activity is the eruption of dacitic welded tuff of pyroclastic flow origin. Just after this eruption, the site of volcanic activity subsided to form a lake, in which the sediments were deposited, attaining to about 26-50 $\mathrm{m}$ thickness. During the period of the lake's existence, the volcanism was commonly of air-fall type. Cessation of eruption often took place as indicated by the intercalation of black shale in the tuffaceous sediments. Ejecta of this stage were mainly ash and lapilli of rhyolitic to rhyodacitic composition. Thus, the chemical compositions of the volcanic rocks became more and more acidic, from andesitic to rhyolitic. The volcanism of this stage was succeeded by the eruption of rhyolitic tuff and tuff breccia of probably pyroclastic flow origin. They covered the lacustrine sediments and/or abutted on the adjacent dacitic to andesitic rocks.

The last stage of volcanic activity is characterized by the intrusion of 
voluminous volcanic breccias. The existence of the abundant angular to subangular fragments of older volcanics, the brecciation of basement rocks observec at Katsuragatani, and the characteristic feature of pumiceous materials noticed in the Kibe mass, suggest the violent explosive action during their intrusion. The presence of partly vitrified rounded fragments of basement rocks implies the brecciation at deeper level, while rhyolitic rocks must have been captured at the present level or adjacent to it since they occur as angular and large blocks. The brecciation of the andesitic rocks appears to have occurred at somewhat deeper level than that of rhyolitic rocks. However, it must be noted that the pronounced amount of andesitic rocks appear to have been transported from the underground level beneath the present contact with the basement rocks.

From the above-cited results three stages can be identified in the formation of volcanic breccias as described below.

1) Brecciation of basement rocks and previously consolidated andesitic rocks at comparatively deeper level. The mechanism of such underground brecciation has been discussed by many workers. Gates (1959), Krushensky (1963) and Parsons (1967) suggested the mechanism by solution stoping, explosive eruption, gas fluxing and explosion, and rock burst. Of these causes, Parsons (1967) cited gas explosion as a contributing factor. Wright and Bowes (1968) considered the explosive activity in the formation of the explosion-breccia is intimately related to the sudden release of gas. The role of gas appears to have been very important in the formation of the volcanic breccias in the Zenjoji-yama formation, as well. As will be stated later, the writers regard the production of a large volume of volcanic breccias in the Zenjoji-yama formation as mainly due to the vaporization of the water derived from the caldera lake and its explosion in the magma chamber.

2) Upward shift of brecciated fragments mingled with vesiculating unconsolidated magma. They might have been carried by the current of streaming gas through pressure differentials along vents and fissures. The transported rock fragments became more and more rounded through the repetition of the abrasion within gas-tuff streams as discussed by Reynolds (1954), Wright and Bowes (1968) and Bryant (1968).

3) Intrusion of the breccias into the upper volcanic formation. The component volcanic rocks were shattered by the successive gas explosion and the friction with the migrating rock fragments to form blocks of various sizes. The volcanic rocks breached by these actions were moved upward together with gas-tuff stream and brecciated the volcanic rocks at upper horizon, leaving behind the undestroyed tilted large blocks.

4) Part of the fluidized breccias was poured out on the surface as observed 
in the Kibe and Zenjoji-yama masses.

From the above description, the volcanic breccias in the Zenjoji-yama formation seem to correspond to the explosion-breccia or intrusive explosion breccia of Wright and Bowes (1963) and Fisher (1960).

As for the underground gas explosion in the formation of the volcanic breccias under consideration, the writers consider that it is closely connected with the formation of cauldron structure (depression caldera) during the volcanic activity. The following gives evidence to the plausibility of this consideration.

1) The formation of lacustrine deposits after the eruption of a large volume of pyroclastics and lava flow of stages I and II. This distribution is confined to the nearly central part of the volcanic area except for the Zenjojiyama mass.*

2) The possiblity of the existence of volcanic formation of stage I at deeper underground level beneath the present contact with the basement rocks, as discussed before.

3) The existence of the marginal fault surrounding the volcanic formations of stages $I$ and II. Although the fault is obscured by the intrusion of the volcanic breccias, it is presumed that the fault might have made up a continuously elongated ring-shaped tectonic zone around the volcanic formations before the emplacement of the volcanic breccias, as deduced from the distribution of these breccias.

As a result of these discussions, it can be safely said that the volcanic area sunk after the eruption of the volcanic rocks belonging to stage $I$ and the first half of stage II. The caldera lake was formed within the depressed area probably surrounded by the ring-shaped wall. The lacustrine sediments were deposited in this lake, but the lake disappeared before the eruption of rhyolitic pyroclastics showing the deposition on land, although the cause of its disappearance is not clear. Succeeding the eruption of the rhyolitic pyroclastics, a considerably large amount of volcanic breccias intruded along the marginal fault and other fractures, and invaded into the pyroclastics and unconsolidated sediments, which were destined to be destroyed and fragmented. These processes are similar to those in the formation of volcanic breccia pipe described by Gates (1959).

The formation of ring-shaped fractures might have continued thereafter, judging from the distribution of the plutonic complex of stage IV in the Kibe

* The lacustrine formation in this mass exists not only in the central part but also in the eastern margin. However, in the latter, the formation makes up the tilted block surrounded by the fault pattern of the later stage. 
mass. These fractures may be in close association with the upward compression by the underground magma during and /or after the volcanism of stage III.

A brief discussion on the formation of the volcanic breccias is given here, as the water in the caldera lake is considered to have played an important role. Within the cauldron, the collapsed volcanic formations were broken into blocks of several sizes as subsidence progressed, until they sunk into the magma reservoir. Then, violent gas explosion occurred when a large amount of water accompanied by sunken blocks mingled with magma. Through these processes the chemistry of magma must have undergone a change as a result of contamination by the incorporated volcanic rocks largely of andesitic composition. Figures 8 and 9 may suggest this possibility. As shown in both figures, the chemical compositions of the breccias lie near the border area between those of stages I and II. The proposition that the compositions of the breccias are attributed to the contamination of rhyolitic magma by the sunken andesitic rocks might well elucidate this fact. Kuno (1953) proposed the similar process in the formation of Krakatoan type caldera.

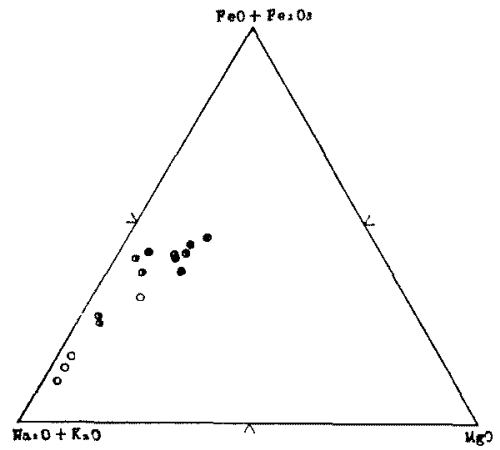

Fig. 8

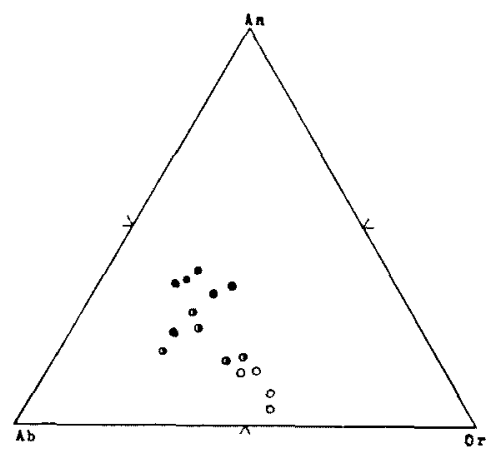

Fig. 9.

Fig. 8. $\mathrm{MgO}-\left(\mathrm{FeO}+\mathrm{Fe}_{2} \mathrm{O}_{3}\right)-\left(\mathrm{Na}_{2} \mathrm{O}+\mathrm{K}_{2} \mathrm{O}\right)$ triangular diagram.

Solid circle: Volcanic rocks of stage I.

Open circle: Volcanic rocks of stage II.

Half solid circle: Volcanic rocks of stage III.

Fig. 9. An-Ab-Or triangular diagram.

Symbols are the same as those in Fig. 8.

\section{SUMMARIZED HISTORY OF VOLCANISM IN THE ZENJOJI-YAMA FORMATION}

The history of volcanism in the Zenjoji-yama formation can be summarized in the order of succession as follows: 
Intrusive volcanic breccias in the late Mesozoic Zenjoji-yama formation 89

Stage I: The eruption and deposition of andesitic lava flow and pyroclastics on land.

Stage II: The extrusion of dacitic pyroclastics succeeded by the formation of a caldera lake in which lacustrine tuffaceous sediments were deposited. During this deposition volcanic activity of air-fall type took place. After a meanwhile the rhyolitic pyroclastic flow deposits covered the lacustrine sediments. Probably, the lake might have become extinct regardless of the continued formation of cauldron structure.

Stage III: The invasion of volcanic breccias. Within the magma

Table 2. Volcanism, plutonism and crustal movements in the Zenjoji-yama formation, West Chugoku

\begin{tabular}{|c|c|c|c|}
\hline Stage & Volcanics & Mode of occurrence & $\begin{array}{c}\text { Crustal movement \& } \\
\text { plutonism }\end{array}$ \\
\hline IV & & & $\begin{array}{l}\text { Plutonism } \\
\text { (Ring dike) }\end{array}$ \\
\hline III & $\begin{array}{l}\text { Rhyodacite to dacite } \\
\text { (Volcanic breccia and } \\
\text { welded tuff) }\end{array}$ & $\begin{array}{l}\text { Intrusives to pyro- } \\
\text { clastic flow }\end{array}$ & $\begin{array}{l}\text { Formation of ring } \\
\text { fracture }\end{array}$ \\
\hline II & $\begin{array}{c}\text { Rhyolite } \\
\text { Dacite } \\
\text { (Tuff, tuff breccia, } \\
\text { welded tuff with } \\
\text { tuffaceous sediments) }\end{array}$ & $\begin{array}{c}\text { Pyroclastic flow with } \\
\text { pyroclastic fall }\end{array}$ & $\begin{array}{c}\text { Extinguishing of } \\
\text { caldera lake }\end{array}$ \\
\hline $\mathrm{I}$ & $\begin{array}{l}\text { Augite andesite and } \\
\text { hornblende-augite } \\
\text { andesite } \\
\text { (Tuff, tuff breccia } \\
\text { and lava) }\end{array}$ & $\begin{array}{l}\text { Lava flow and pyro- } \\
\text { clastic flow }\end{array}$ & $\begin{array}{c}\text { lake } \\
\text { Subsidence(cauldron) }\end{array}$ \\
\hline $\begin{array}{l}\text { Late } \\
\text { Creta- } \\
\text { ceous }\end{array}$ & $\begin{array}{l}\text { Andesite to dacite } \\
\text { (Kwanmon group) }\end{array}$ & $\begin{array}{l}\text { Largely pyroclastic } \\
\text { fall }\end{array}$ & $\begin{array}{l}\text { Faulting (NNW-SSE) } \\
\text { \& plutonism }\end{array}$ \\
\hline
\end{tabular}


chamber, the aqueous magma contaminated by the sunken andesitic blocks and water caused a violent gas explosion together with fragmentation of the blocks and destruction of wall rocks. The mingled gas-fragment stream moved upward and intruded the volcanic formation at upper horizon, brecciating it. Part of the breccia flow was poured out on the surface.

Succeeding the volcanic activity, the plutonic complex ranging from gabbro to granodiorite intruded along the elongated ring-shaped fracture which might have been formed during and/or after the volcanism of stage III.

The above-described hisotry of the igneous activity in the Zenjoji-yama formation is illustrated in a table (Table 2).

\section{CONCLUSION}

1) Detailed investigation of the intrusive volcanic breccias in the Zenjojiyama formation reveals that the breccias are in intimate connection with the formation of cauldron structure.

2) The breccias were formed as a result of the contamination of rhyolitic magma by the sunken andesitic blocks and water. Gas explosion in the magma chamber appears to be a main contributive factor in the underground brecciation.

3) Brecciated fragments fluidized upward together with gas-tuff stream to destroy the volcanic rocks at upper horizon. Part of the breccias was poured

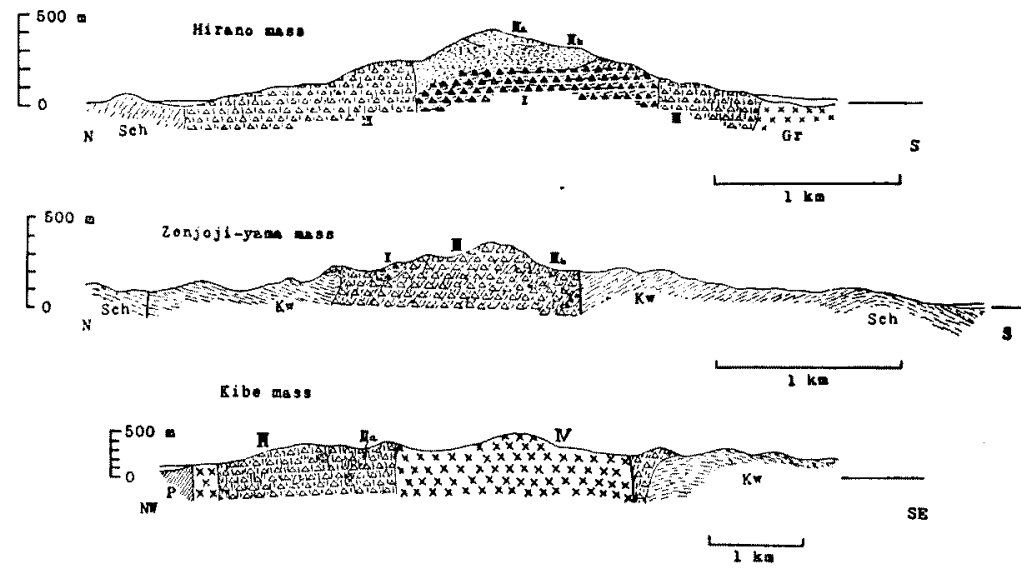

Fig. 10. Geological profile of the Zenjoji-yama formation.

I, IIa, IIb, IIc, III and IV represent the volcanic and plutonic rocks of respective stages. Gr: Late Mesozoic granites. $\mathrm{Kw}$ : Kwanmon group. P: Upper Palaeozoic formation. Sch: Sangun metamorphic rocks. 
Intrusive volcanic breccias in the late Mesozoic Zenjoji-yama formation 91
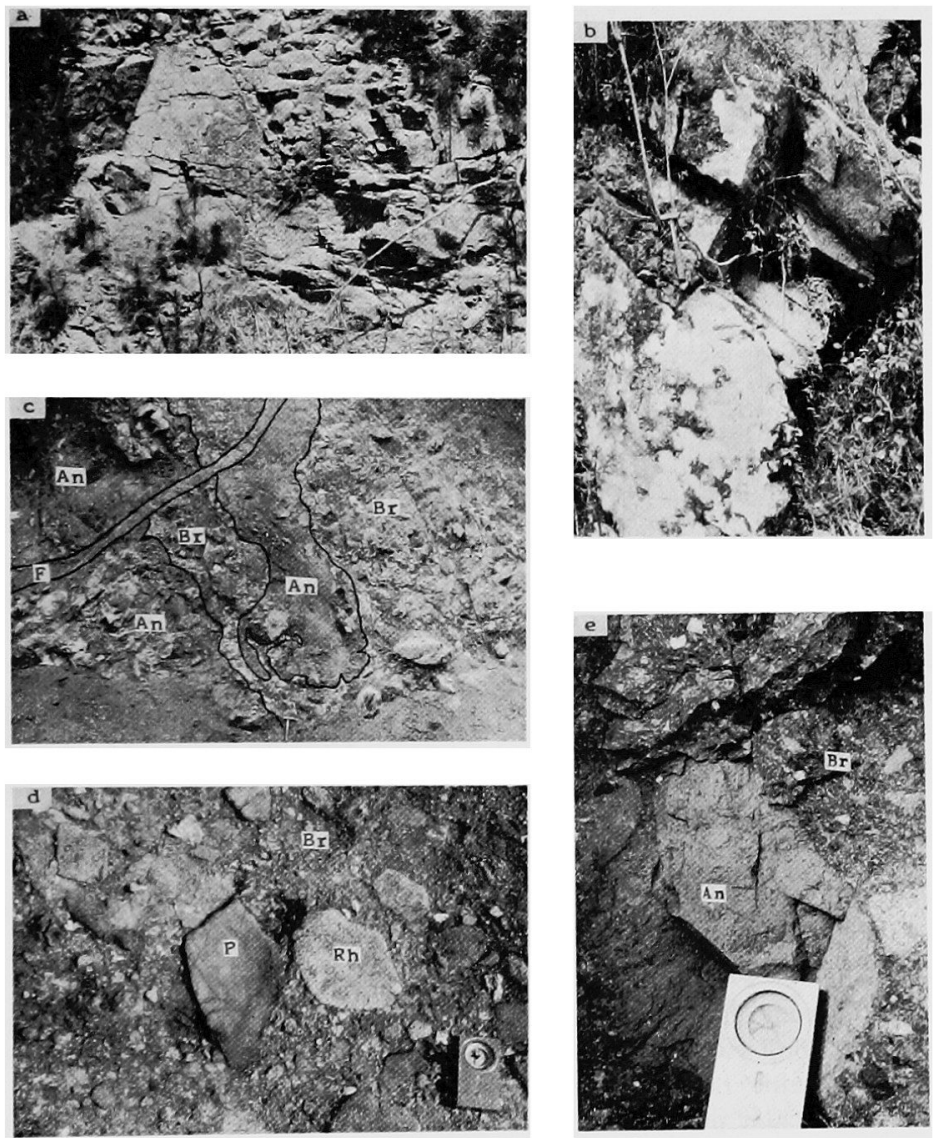

Fig. 11. Photographs showing the occurrence of volcanic breccias.

a : Layered andesitic tuff formation of stage I. Almost horizontal bedding is prominent (Kibe mass).

b: Layered rhyolitic tuffaceous sediments of stage II (Kibe mass).

c: Volcanic breccia intruded into the andesitic formation of stage $I$. Lenticular pumiceous materials aligned along the contact are observed (Kibe mass). Br: Volcanic breccia. An: Andesite. F: Fault.

d: Volcanic breccia containing various sizes of rock fragments composed mainly of rhyolitic tuffs and basement rocks (Palaeozoic) (Kibe mass). $\mathrm{Rh}$ : Rhyolitic tuffs. $\mathrm{P}$ : Basement rocks. Br: Volcanic breccia.

e : Volcanic breccia containing large andesitic block. Pumiceous materials are arranged lenticularly around the block (Kibe mass). An: Andesite. Br: Volcanic breccia. 

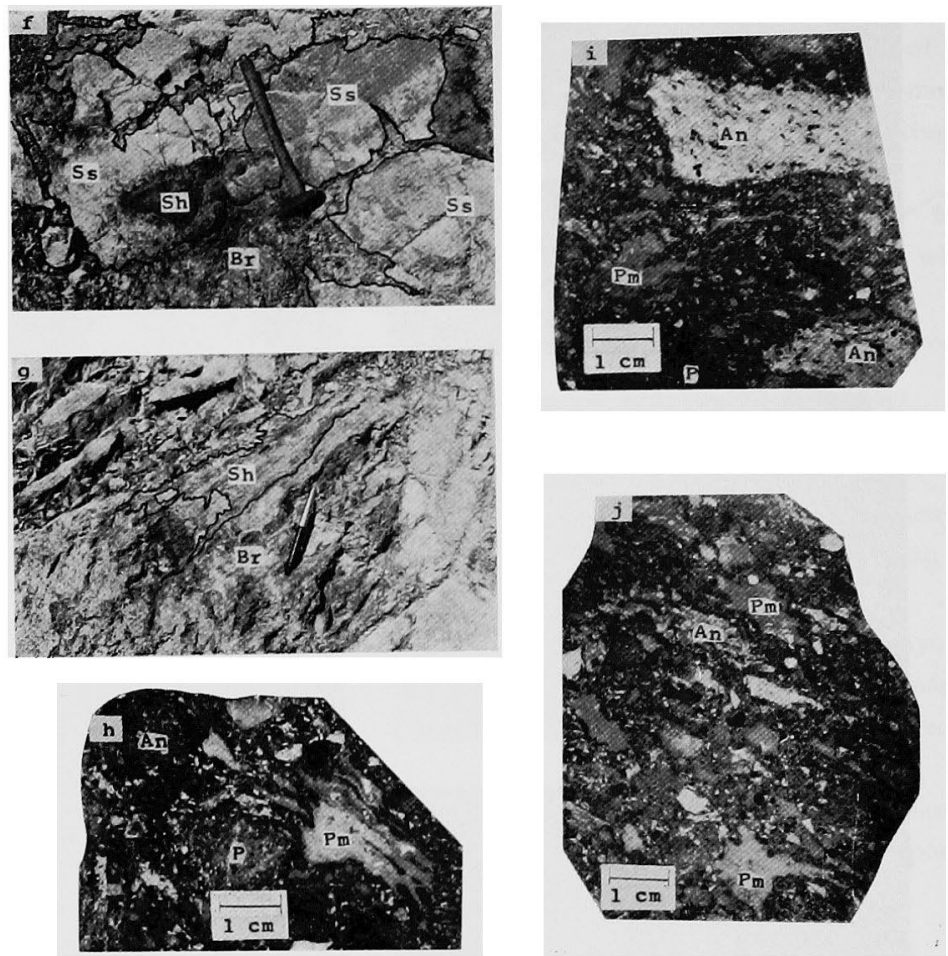

Fig. 11. Continued

f-g : Volcanic breccia intruded into the tuffaceous sediments of stage II (Zenjoji-yama mass.) Ss: Sandstone. Sh: Shale. Br: Volcanic breccia.

$\mathrm{h}-\mathrm{j}$ : Volcanic breccia containing various types of rock fragments and lenticular pumiceous materials (Kibe mass). An: Andesites. P: Basement rocks (Palaeozoic). Pm: Pumiceous materials.

out on the surface.

4) The contamination by the sunken andesites might have affected the chemistry of magma until the magma was transformed into rhyodacitic to dacitic composition.

5) The volcanism was succeeded by the intrusion of ring-shaped plutonic complex which is possibly of comagmatic origin with volcanic rocks.

6) It is noted that the cauldron in the fissure eruption-type volcanic area takes a subvertically dipping elongated from controlled by the main tectonic lines. 
Intrusive volcanic breccias in the late Mesozoic Zenjoji-yama form ition 93

\section{ACKNOWLEDGEMENT}

We wish to express our sincere thanks to several members of the "Research Group for LMIA (Late Mesozoic Igneous Activity in Southwest Janan)" who provided assistance during the course of investigation. We are also indebted to Dr. K. Nakamura of Tokyo University for helpful advice on the classification and nomenclature of volcanic breccias. A part of the expenses of this study was defrayed by the Grant in Aid for Scientific Researches from the Ministry of Education.

\section{REFERENCES}

Bryant, D.G. (1968), Intrusive breccias associated with ore, Warren (Bisbee) mining district, Arizona. Econ. Geol., 63, 1 12.

Fisher, R.V. (1960), Classification of volcanic breccias. Bull. Geol. Soc. Am., 71, 973 982.

Gates, O. (1959), Breccia pipes in the Shoshone range, Nevada. Econ. Geol., $54,790 \sim 815$.

Ichikawa, K., Murakami, N., Hase, A. and Wadatsumi, K. (1968), Late Mesozoic igneous activity in the inner side of Southwest Japan. Pacific Geology, 1, 97 118.

Krushensky, R. (1963), Origin of volcanic breccias, northern Absaroka range, Wyoming-Montana. Geol. Soc. Am. Spec. Paper, 76, 96.

Kuno, H. (1953), Formation of caldera and magmatic evolution. Transac. Am. Geophy. Union, 34, 267 280.

Murakami, N. (1960), Cretaceous and Tertiary igenous activity in western Chugoku, Japan. Sci. Rep. Yamaguchi Univ., 11, 21 126.

____ and Nishino, H. (1967). Volcanostratigraphical studies of the late Mosozoic acid rocks in western Chugoku. Part 2. ibid., 17, 35 40.

Nishino H. and Murakami, N. (1905), Volcanostratigraphical studies of the late Mesozoic acid rocks in western Chugoku. Purt 1. ibid., 15, 9 19.

P.ursons, W.H. (1967), Munner of cmplacement of pyroclastic andesitic breccias. Bull. Volc., 30, $157 \sim 187$.

Research Group for IMIA (1967). Iate Mesozoic igneous activity and tectonic history in the Inner Zone of Southwest Japan. Monogr. Assoc. Geol. Collab. Japan, 12, $1 \sim 51$.

Reynolds, D.L. (1954), Fludization as a geological process, and its bearing on the problem of intrusive granites. $\Lambda \mathrm{m}$. Jour. Sci., 252, $577 \sim 613$.

Smith, R.L. (1960), Ash flows. Bull. Geol. Soc. Am., 71, $795 \sim 842$.

Wright, A.E. and Bowes, D.R. (1963), Classification of volcanic breccias: A discussion. Bull. Geol. Soc. Am., 74, 79 86.

___ and - (1968), Formation of explosion-breccia. Bull. Volc., 32, $15 \sim 32$. 


\section{蔐 要 \\ 中国西部禅定寺山累首中の貫入性火山角硨岩類，および \\ それらと陷没構造との関連}

村上允 英·松 里 英 男

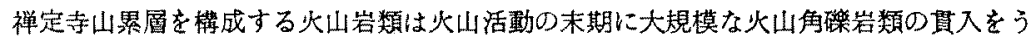
けている。これらの角砅岩類の性状を詳細に検討した結果，ての生成が炎山体内における 陷没構造の形成之密接な関連のあることが明らかとなった。おそらく，角磂岩類はマグ、 溜り中における沈降した安山岩塊および $\mathrm{H}_{2} \mathrm{O}$ とマグマとの混成，大規模ながス爆発，上 方への流動化，などの過程を経て形成されたものであるう。いわゆる割目噴出を行なった

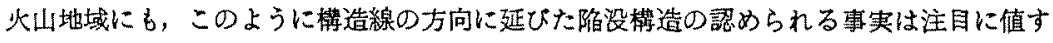
る。なお，火山岩類は環状の㓶目にそって同一マグマ起源と考えられる深成岩類の貫入を うけている。 